\title{
Teacher Career Development Cases Indonesia
}

\author{
Muradi*, Sudidul Aji, Onik Farida Ni'matullah \\ Master of Social Science Education Study Program \\ University Kanjuruhan Malang \\ Malang, Indonesia \\ *muradisyam@gmail.com, sudi@unikama.ac.id, onikfarida@unikama.ac.id
}

\begin{abstract}
The objective of this research was to understand comprehensively the development of teachers' career at the Pamekasan Regency. it was a quantitative research. The population in this study were all teachers who were members of the Sociology Subject Teacher Association in Pamekasan Regency as many as $\mathbf{7 3}$ people. This research technique does not use sampling techniques but uses population research. The data collection method used a questionnaire, while the questionnaire was tested on 30 out-of-target teachers with validity and reliability tests. Hypothesis testing using partial test with $t$ test and simultaneous test using $F$ test. Data analysis using simple regression and multiple regression with the help of a computer. The results of this study found evidence that education, training, and career development programs affect teacher competencies in the Sociology Subject Teachers Meeting in Pamekasan Regency. There are many ways that must be done in order to increase career development and professional teachers, among others, with education and training as well as good supervision. This research needs to be followed up, especially with regard to different variables such as quality management and competence of school principals, quality curricula, funding and so on which contribute to teacher performance.
\end{abstract}

Keywords—career development, education, and training

\section{INTRODUCTION}

Someone's performance can be improved if there is suitability between his job and ability, the same as the placement of teacher on his field. Placing teacher based on the ability absolutely must be conducted. According to Zainal [1] if teacher is given task which is not suitable on his ability, it will cause decreasing their procedure and work result, and also raise self-dissatisfaction that resulted in career development.

The improvement of teacher performance on the professionalism development side as teacher is absolutely needed. In response the importance of teachers performance, the government has legitimized the Law No 14 of 2005 [2] about Teacher and Lecturer in implementing the profession, teacher is entitled: (a) getting the salary above the minimum file necessities and the guarantee of the social welfare; (b) getting the promotion and award based on the task and work achievement; (c) getting the protection in implementing the task and right to intellectual property; (d) getting the opportunity to increase the competence; (e) getting and utilize the learning facilities and infrastructure to support the smooth professional duties; (f) having freedom of giving assessment and taking part in deciding graduation, award, and/or penalty to the students based on the educational principles, teacher code of ethics, and legislation; (g) getting the sense of secure and the safety guarantee in implementing task; (h) having freedom to unite in professional organizations; (i) having opportunity to take part in deciding the educational policies; (j) getting opportunity to develop and improve academic and competence qualification; and/or (k) getting training and profession development based on the field.

The study of Saragih [3] titled "The influence of organization, professionalism, and achievement motivation towards Percut Sei Tuan State of Junior High School teachers performance in Deli Serdang District" stated that increasing the teachers performance through teacher professionalism needs efforts from many parties: the headmaster as the leader is the one who decides the teacher's performance especially related to the policy of each teacher professionalism. Building the professionalism in better teaching and giving certainty that the quality of learning can be conducted and the performance would be much better, so in giving learning teacher would be more professional, therefore students would be more excited and motivated to learn. Teacher who has high professionalism is very relevant with the teacher task as a person who transfers knowledge and skill to the students. When an approach method does not give maximum result, teacher must not be giving up, but he must be sure that there will be other way that makes students more successful. This is an application of professionalism concept which makes maximum work quality. The result of the study showed that: there was direct influence between teachers professionalism towards Percut Sei Tuan State of Junior High School teachers performance in Deli Serdang District in the amount of $42 \%$ and the rest was $58 \%$, it showed that the higher the Professionalism is, the higher Percut Sei Tuan State of Junior High School teachers performance in Deli Serdang District.

Moreover, based on the study which was conducted by Harlie [4] titled "The Influence of work discipline, motivation, and career development towards employees performance in Tabalong District Government in Tanjung Kalimantan selatan" stated that the result of $\mathrm{T}$-test earned the $\mathrm{t}$ value for the discipline work (X1) variable in the amount of 7,330, for the 
motivation (X2) value was 6,155 , the career development (X3) value was 5.045 , and the $t$ table was 1,6599 . It was meant that $t$ value $>\mathrm{t}$ table, so Ho was rejected and $\mathrm{Ha}$ was accepted which meant the independent variable that covered work discipline (X1), motivation (X2), and the career development (X3) partially influenced towards employees performance (Y) in the district government Tabalong in Tanjung Kalimantan Selatan.

Based on the information above, it shows that teacher is one of the educational elements which plays an active role and places the position as a professional teacher to increase the educational quality in Indonesia in order to get out of the educational problems. But In reality, the quality of education in Indonesia is still in trouble. The government has tried to increase the quality of education in Indonesia through giving training to the teachers, raising the salary, procurement of facilities and infrastructure, even has given scholarship to increase the education level, but it did not give significant influence towards the increasing of education level.

Teacher who does not show high performance in implementing the task, will always suppose that teaching is only transferring various knowledge to the students in school. So without the sincerity, teacher thinks that knowledge can be found by the students themselves. Such thoughts will be a serious threat for the education world in our country, because if this concept is developing so the rise of education in our country will not be realized

There is teacher who does not seriously show the performance, unvaried learning, skill in implementing task, assessment of poor learning outcomes is the indication of teacher low performance. With many kinds of reasons, teacher does not prepare the learning as maximum as possible, low presence and does not show the skill based on the competence of professional in school [5].

Based on the observation in the field there are teachers who do not arrange the teaching administration, such as lesson plan. Furthermore there are teachers who often absent for no apparent reason, teachers who teach not according to their expertise, teachers are not discipline to come in class, the presence in school meeting is only average $60 \%$ up to $80 \%$, low teachers participation in taking decision, many teachers are function to teach only, teachers who are involved on extracurricular only 5-10\% and Teachers Professional Development Forum (MGMP) has not functioned well.

Through the direct observation that was conducted to the Sociology Teachers Professional Development Forum (Sociology MGMP) in Pamekasan District, when the learning activity is running there are teachers who teach by asking students only to make note, classroom is relatively empty that shows teachers are lazy to teach, there are teachers who come and go home not in accordance with office hours, even there is teacher who never make evaluation in learning process. Furthermore, there are teachers who almost 20 years teach and they never get job promotion and also teachers who teach for many years without any action. It shows that teacher performance in Sociology MGMP Pamekasan District was still low. Eventually it would affect the purpose and educationa level in Pamekasan District and also the teacher career development.

From those fact shows that teacher performance in Sociology MGMP Pamekasan District has not have good performance and can be stated that the cause is low professionalism and development competence of the teacher. Teacher as educator and teacher cannot be just separated, but teacher must get more guidance towards profession development, direction, and career improvement motivation.

Finding many problems which affect the good performance both empirical and conceptual so this thing can be used to understand, predict and find alternative of performance problem phenomenon. Based on the explanation above, teacher career development is importantly researched to know the influence of those variables towards teacher performance improvement. Based on this thought, so it is planned to make research titled "The Influence of Teacher Performance Towards Career Development of Senior High School Teacher in Pamekasan District."

\section{METHODS}

The type of this research is quantitative research using SPSS 18 data analysis. This study used a quantitative approach using SPSS 18 data analysis. The sampling technique used was total sampling where the total number of sociology teachers was used, as many as 73 sociology teachers joined in the sociology subject teacher deliberation in Pamekasan district. with data collection in this study using a questionnaire. Test instruments in this study using validity and reliability. Data analysis techniques using multiple regression analysis, classical assumption test and hypothesis testing. Multiple regression analysis is used to determine the effect of independent variables on the dependent variable. The classic assumption tests used are normality test, multicollinearity test, heteroscedasticity test, autocorrelation test. While the hypothesis test used is the $t$ test.

\section{RESULTS AND DISCUSSION}

In educational institution, teacher is the most decisive and influential factor on educational level. As a person who is responsible to educational level, teacher should show high performance. The higher teacher performance is, the more possibility reached of educational level. Many factors that affect teacher performance, namely Human Resource participation, career development, communication, health, and work safety, problem solving, good incentive and pride. On the other word, those factors are the teacher motivation to increase performance. When someone has low motivation, it will produce low performance. It is the same as someone has high motivation, so the performance will be increased as well.

The result of the research showed that there was a career development positive influence on career development of Senior High School teacher in Pamekasan District. It was shown by the significance of Value F coefficient in the amount 
of $163.453>$ table F 2,947 on the level of significance was 0,00 . The result of data analysis showed that there was significant and meaningful relation between career development and teacher performance. Thus, it can be concluded that career development has relation with teacher performance in Pamekasan District. It meant that the better career development, the better teacher performance in Pamekasan District as well.

There was a significant and meaningful relation between professional development and teacher performance in Pamekasan District. Thus, it can be concluded that professional development has relation with Senior High School teacher performance in Pamekasan District. It meant the better professional development, the better senior high school teacher performance as well. There was a meaningful and significant between career development and professional development together with senior high school teacher performance in Pamekasan District. So, it can be concluded that career development and professional development has relation with senior high school teacher performance in Pamekasan District. It meant that the better career development and professional development, the better teacher performance as well in Pamekasan District.

Career development showed a positive and significant relation with teacher performance, so the effort to increase teacher performance is increasing the career development quality. Based on the findings, it was shown some implication related to the effort to increase the career development. The headmaster must be able to be the best leader in the school that always develop teachers' career in order to increase the performance.

Career development has a significant role in increasing teacher performance. Headmaster has responsibility in supporting and giving motivation to the teacher in order to keep increasing their performance.

The city government is the main director in increasing teacher performance, so in achieving good teacher performance must refer to Law No 14 of 2005 about teacher and lecturer. The increasing of teacher competence and performance become the responsibility of regional government, headmaster, and teacher himself. So, it needs real efforts from the regional government in implementing guidance, training, and increasing human resource for the headmaster and teacher to realise good teacher performance. Teacher career development started from accepting as a teacher until entering retirement. In the career development, teacher has two career paths, namely through structural and functional path. Career development for a teacher is one of the supports in increasing performance so, what is school needed would be achieved. Career and profession development are directed to increase competence and teacher performance in implementing educational learning process in class and out of class. The effort of increasing competence and professional must be in line with the effort of giving award, increasing welfare, and teacher protection. This activity becomes integral part of professional development sustainably.

The effort to increase teacher performance can also create good professionalism. Based on creating good teacher performance so it needs to increase the teacher professional through various ways, such as the guidance by headmaster, education unit supervisor, regional government through education authorities, education, and sustainably practices and so forth that can create good teacher performance.

Educator is an important profession in nation's life. It is because of the education position is very important in the context of nation's life. Educator is dominant element in an educational process, so the quality of education is more decided by educator quality in implementing the role and task in the society. Teacher professional development must be admitted as a fundamental and important thing in order to increase the educational level. Professional development is a process where the teacher and headmaster learn, increase and use the knowledge, skill and value appropriately.

The effort that can be implemented to increase teacher performance is by increasing the career development and professionalism development. Many ways that must be done to increase career development and teacher professional, namely by education and practice, good supervising, adequate compensation, giving motivation and the most important is creating commitment in school organization.

The other program that can be developed is facilitating the educator of the educational unit to conduct research about education. The result of the research was written in a research report form based on the applicable provisions in writing scientific work. So, the educators must have a skill in research field and writing scientific work. The skill can be earned through education and training about educational research and writing scientific work. Profession and career development are directed to increase the competence and teacher performance in implementing educational and learning process in class and out of class. The effort to increase the competence and professional must be in line with the effort to give award, increasing welfare, and teacher protection. This activity becomes integral part of the teacher professional development sustainably.

In the Law Number 20 of 2003 about national education system of teacher performance related to the teacher competence, means that to have good performance, teacher must be supported by the good competence. Without having good competence, a teacher will not possibly have good performance. Teacher who works well will increase the school productivity that will succeed the school purpose. In succeeding the school purpose, a teacher must master 10 (ten) competences that is basic skill of teacher. There are: (1) mastering the material; (2) managing teaching and learning program; (3) managing class; (4) using the media and learning source; (5) mastering the education base; (6) managing teaching and learning interaction; (7) evaluate students achievement for lesson needs; (8) knowing function and program of counselling and guidance service; (9) knowing and 
conducting school administration; (10) understanding principal and interpreting the result of the research for teaching needs.

Career and professional development of educator is implemented in increasing the grade and functional position which has professional skill and performance. Therefore, career and professional development of educator is planned effort to help the educators in increasing the grade and their position through gathering functional position credit number. The increase of grade and position must indicate the increasing professional skill and performance as professional educator.

\section{CONCLUSIONS}

- To increase the teacher performance, hope for all sides have important role in advancing education started from main government through ministry of education and culture, business world, school committee, legislative member, headmaster, either the teacher himself or the students must be able to cooperate and give more attention in trying to create good teacher performance. Because the teacher performance will affect the increase of educational quality, moreover it is related to the teacher career development.

- Except the career development factor that is related to the teacher performance development, a teacher needs to be supported by the change of many aspects in education, one of those is by creating professional development.

- To the other researcher, this research needs to be followed up, especially related to the different variables, such as quality management and headmaster competence, quality curriculum, financing, and so on that give contribution to the teacher performance related to the teacher career development.

\section{REFERENCES}

[1] A. Zainal, Teacher Professionalism in Learning. Surabaya: Insan Cendikia. 2010

[2] Law Nomber 14 of 2005, about Teacher and Lecturer. Ministry of Education and Culture.

[3] J. Saragih, "The Influence of Organization Climate, Profesionalism and Motivation of Achievement on the teacher performance of State Junior High School Percut sei Tuan, Dei Serdang District”. (Master Thesis). The State University of Medan. 2012.

[4] M. Harlie, The Influence of Work Discipline, Motivation and Career Development on the Governemnet Employee in Tabalong District Government in Tanjung Kalimantan Selatan. "Management Application Journal". Vol 10 no 4. 2012.

[5] M. Alpian, "The Relation between Competence and Teacher Professionalism Development in the Form of Teacher Professional Development Forum (MGMP) by Increasing the School Level in Islamic Junior High School of Binjai. (Matster Thesis)". The State University of Medan. 2012 